\title{
A Comparison Between Modified Radical Mastectomy and Breast-Conserving Surgery Concerning the Quality of Life in Patients with Breast Cancer Under 50 Years of Age
}

\author{
Elli Yaș Altı Meme Kanseri Hastalarında Modifiye Radikal Mastektomi ve \\ Meme Koruyucu Cerrahinin Yașam Kalitesi Açısından Karșılaștırılması
}

\author{
Ozlem ELMAS ${ }^{1}$ (D), Guldeniz KARADENIZ CAKMAK ${ }^{2}$ (D), Bekir Hakan BAKKAL ${ }^{1}$ \\ ${ }^{1}$ Zonguldak Bulent Ecevit University, Faculty of Medicine, Department of Radiation Oncology, Zonguldak, Turkey \\ ${ }^{2}$ Zonguldak Bulent Ecevit University, Faculty of Medicine, Department of General Surgery, Zonguldak, Turkey
}

ORCID ID: Ozlem Elmas 0000-0001-8039-9610, Guldeniz Karadeniz Cakmak 0000-0001-5802-4441 Bekir Hakan Bakkal: 0000-0003-1799-5377

Cite this article as: Elmas O, Karadeniz Cakmak G, Bakkal BH. A Comparison Between Modified Radical Mastectomy and Breast-Conserving Surgery Concerning the Quality of Life in Patients with Breast Cancer Under 50 Years of Age. Med J West Black Sea. 2021;5(1):63-67.

Corresponding Author Bekir Hakan Bakkal

E-mail

bhbakkal@yahoo.com

\begin{abstract}
Aim: To compare the quality of life in breast cancer patients, who have undergone breast-conserving surgery (BCS) to those having undergone modified radical mastectomy (MRM).

Material and Methods: Forty-four BCS and 27 MRM patients have been included in this retrospective study. All patients have completed adjuvant chemotherapies and radiation therapies. MRM patients who received breast reconstruction surgery afterwards, patients who experienced local or distant organ relapse, or patients over fifty years old have been excluded. Each patient's quality of life has been evaluated using the Short Form 36 (SF-36), 6 months after the completion of their treatment.

Results: Between BCS and MRM groups, no significant difference of age, height, weight and body mass index was observed. While the BCS group yielded better results from the SF-36 subscales, i.e. physical functioning, physical role functioning, emotional role functioning, social role functioning, bodily pain, and general health perceptions, the only measures illustrating a significant difference were vitality and mental health, in comparison of BCS with MRM group ( $p=0.043$ and $p=0.023$, respectively).

Conclusion: In the treatment of breast cancer, enhancing patients' quality of life is just as essential as improving survivals. Our research demonstrates higher quality of life in BCS patients, highlighting the statistical difference of the vitality and mental health subscales of the SF-36, compared with the MRM group.

Keywords: Breast cancer, Quality of life, Mastectomy, Breast-conserving surgery
\end{abstract}

öz

Amaç: Meme koruyucu cerrahi (MKC) ve modifiye radikal mastektomi (MRM) uygulanmış meme kanserli hastaların yaşam kalitelerinin karşılaştırılması.

Gereç ve Yöntemler: Kırk dört adet MKC ve 27 adet MRM uygulanmış meme kanserli kadın hasta bu retrospektif çalışmaya dahil edilmiştir. Tüm hastalar adjuvan kemoterapi ve radyoterapilerini tamamlamıştır. MRM sonrası meme rekonstrüksiyonu yapılanlar, lokal ya da uzak organda tekrarlama gelişenler ve elli yaşın üstünde olanlar çalışmadan çıkarılmıştır. Tüm tedavilerin tamamlanmasından 6 ay sonra hastaların yaşam kalitesi Kısa Form 36 (SF-36) ile değerlendirilmiştir.

Bulgular: MKC ve MRM grupları arasında yaş, boy, ağırlık ve vücut kitle indeksi açısından anlamlı fark yoktu. SF-36 ölçeklerinden fiziksel fonksiyon, fiziksel rol güçlüğü, duygusal rol güçlüğü, sosyal rol 
güçlüğü, ağrı ve genel sağlık algısı ölçeklerinde MKC grubunda MRM grubuna oranla daha iyi sonuçlar çıkmasına rağmen anlamlı fark bulunmazken, sadece vitalite ve ruhsal sağlık ölçeklerinde MKC grubunun değerleri MRM grubunun değerlerinden istatistiksel anlamda daha iyi bulundu (sırasıyla $p=0.043$ ve $p=0.023$ ).

Sonuç: Meme kanseri tedavisinde hastaların yaşam kalitesinin artırıması sağkalımı uzatmak kadar önemlidir. Çalışmamızda MKC hastalarında daha yüksek yaşam kalitesi olduğu gösterilmiştir, özellikle SF-36 ölçeklerinden vitalite ve ruhsal sağlık, MRM grubuna göre istatistiki anlamlı olacak şekilde daha iyi bulunmuştur.

Anahtar Sözcükler: Meme kanseri, Yaşam kalitesi, Mastektomi, Meme koruyucu cerrahi

\section{INTRODUCTION}

Breast cancer is not only the most frequently occurring type, but also the second most lethal cancer in women (1). The diagnosis alone has the ability to increase levels of psychological stress in patients to as high as $75 \%$, which, in turn, leads to a decrease in quality of life (2). Consequently, utilizing the post-surgery summative assessment reported by patients in modern-day clinical research, is of the utmost importance.

Breast cancer surgery is applied in two ways, one is modified radical mastectomy (MRM), the other way is breast-conserving surgery (BCS). Quality of life of the patients is affected after both methods of surgery. Especially, BCS is the first choice of surgical treatment, however for a number of reasons, e.g. if the breast/tumor ratio is not suitable for performing BCS, if diseases like scleroderma disqualifies the patient for radiation therapy (RT), due to the occurrence of multicentric mass, if a negative surgical margin cannot be provided through BCS or due to patient preference, etc., performing MRM may be required.

As time goes by, certain progresses and strides in the field of breast cancer treatment allowed for a longer survey in patients, for this reason improving their quality of life has become more important. The "Medical Outcomes Study (MOS): The Short Form 36" is a survey including 36 questions, which enables researchers to evaluate patients' quality of life based on physical and psychological aspects and, as a tool of measurement, its validity has been scientifically proven in our country (3). The SF-36 is being used to assess quality of life in cancer patients all around the world. Literature on quality of life in patients of certain age groups of breast cancer patients is limited. Our study aims to compare the differences in quality of life of patients with breast cancer treated with MRM/BCS followed by adjuvant treatments, chemotherapy (CT) or RT, by bringing the SF36 survey into service especially in younger breast cancer patients.

\section{MATERIAL and METHODS}

The study was carried out within our Radiation Oncology Clinic retrospectively, between June 2016 and November 2018, including patients with breast cancer post-surgery, who received adequate $\mathrm{CT}$ and $\mathrm{RT}$ treatments. Among the patients, whom have accepted to take part in the study, 44 have undergone BCS and 27 have undergone MRM. Exclusion criteria were patients who had breast reconstruction after MRM, developed local recurrence/distant organ metastases, had ECOG performance status $\geq 2$ and over 50 years of age. During the selection process of MRM, factors like patients' decision, tumor to breast ratio unsuitable for BCS or the existence of multicentric tumors were determinant. Sentinel lymph node biopsy was performed during surgery to all of the patients in the survey.

All the patients were treated with CT followed by RT after surgery. MRM patients received 50 Gy in 25 fractions $R T$ to chest wall whereas BCS patients received 50 Gy in 25 Gy to the whole breast followed by a 10 Gy boost in 5 fractions to the tumor bed (Varian IX, Varian Medical Systems, USA). Supraclavicular and axillary RT (50 Gy in 25 fractions) were administered if the patient had any involved lymph node.

The quality of life in the 71 patients included in the study, has been evaluated using the SF-36 roughly 12 months post-surgery, and at least 2 months after completion of CT and RT. The forms have been filled out during patients' routine control sessions and under the supervision of their physicians. Subsequently, they have been passed on to researchers. The results have been assessed according to the surgery type, in order to show the differences in quality of life.

Our research has been approved by the ethics committee and all participants of the study included have been properly informed and asked to sign a consent form.

\section{Statistical Analysis}

All statistics have been generated using the SPSS 19.0 for Windows (SPSS Inc., Chicago, Illinois, USA) software. The numeric variables' suitability for normal distribution has been analyzed using the Shapiro-Wilk test. The statistics illustrating the numeric variables are the arithmetic mean \pm standard deviation, results in the verbal form have been expressed by numeric values and percentages. In terms of numeric variables, when comparing the two groups, a Student's t-test has been conducted - if a parametric test hypothesis was suggested - to analyze the differences between two averages. If no hypothesis was suggested, the 
Mann-Whitney $U$ test has been used. Verbally expressed variables have been analyzed further by using the chisquare and fisher's exact chi-square test, accepting the value of $p<0.05$.

\section{RESULTS}

All 71 participants of the study were female. 44 of them $(62 \%)$ have undergone BCS and 27 (38\%) MRM. The median participants' age was 43 (range, 27-50). The median age was 44 (range, 31-50) in BCS group, however was 41 (range, 27-49) in MRM group. Stages of patients are summarized in Table 1. Out of 71 patients, 65 (91.5\%) were unemployed, 50 (70.4\%) were non-smokers. None of the patients have practiced alcohol. The difference in height, age, weight and body mass index between two groups was not significant (Table 2).

None of the patients had surgical complication after surgery. Grade 1 complications of radiotherapy were seen in 28 $(63.6 \%)$ and 16 (59.3\%), and chemotherapy in 13 (27.7\%) and $6(22.2 \%)$ of patients of BCS and MRM, respectively. Twelve (25.5\%) and $6(22.2 \%)$ patients experienced grade $\geq 2$ toxicities due to RT $(p=0.156)$, and $6(13.6 \%)$ and 4 $(14.8 \%)$ patients experienced grade $\geq 2$ toxicities due to CT $(p=0.192)$ in BCS and MRM groups, respectively. During the survey none of the patients had a symptom or complaint due to surgery, CT or RT.

Table 1: Stages of the patients

\begin{tabular}{lccc}
\hline & BCS group & MRM group & P \\
\hline IA & $3(6.8 \%)$ & $1(3.7 \%)$ & 0.088 \\
\hline IB & $1(2.3 \%)$ & $1(3.7 \%)$ & 0.682 \\
\hline IIA & $19(43.1 \%)$ & $10(37.1 \%)$ & 0.463 \\
\hline IIB & $16(36.4 \%)$ & $12(44.4 \%)$ & 0.127 \\
\hline
\end{tabular}

BCS: Breast-conserving surgery, MRM: Modified radical mastectomy
The SF-36 entails questions concerning physical functioning, physical role functioning, emotional role functioning, social role functioning, bodily pain, general health perceptions, vitality and mental health well-being, which have been addressed directly to the patients. Even though, with regards to the entirety of parameters, the BCS group yielded better results than the MRM group, only two conveyed significant differences. The following subscales in BCS group have shown no significant difference compared with MRM group: physical functioning (67.16 vs 62.59), physical role functioning (55.56 vs 47.73), emotional role functioning (46.91 vs 43.18), social role functioning (67.59 vs 67.11 ), bodily pain (66.67 vs 65.91) and general health perceptions (69.07 vs 62.84). However, in terms of vitality (63.33 vs 54.89 ) and mental health (71.70 vs 63.18), the BCS group's scores have been significantly higher than the MRM group's ( $p=$ 0.043 and $p=0.023$, respectively) (Table 3 ).

\section{DISCUSSION}

Breast cancer surgery have begun in the 1890s with radical mastectomy, then evolved to MRM in the 1960s and continued on, through the advantages provided by radiation therapy, to the BCS after the 1970s (4). As radical mastectomy has been rendered an outdated surgical technique today, BCS and MRM are the two prevailing choices of breast cancer surgery. Due to conservative surgery being performed in BCS, shape of breast can be substantially maintained. Many issues related to surgery type have been evaluated in literature, including sexual function, quality of life, etc $(5,6)$. Side effects resulting from extensive surgery may not be an issue anymore in BCS, whereas with the addition of RT, patients may experience radiation induced side effects.

Destroyed body image, problems occurring due to surgery/ adjuvant treatments, patients' irritability and fear of death are all factors affecting quality of life in cancer patients. During breast cancer treatment it is aimed to improve the survival rates with maintaining the quality of life of patients,

Table 2: Patients' attributes

\begin{tabular}{lccc}
\hline & BCS group & MRM group & P \\
\hline Median age & $44(31-50)$ & $41(27-49)$ & 0.07 \\
\hline $\begin{array}{l}\text { Employment status } \\
\quad \text { employed }\end{array}$ & $4(9.1 \%)$ & $2(7.4 \%)$ & 1.000 \\
$\quad$ unemployed & $40(90.9 \%)$ & $25(92.6 \%)$ & \\
\hline Smoking & $30(68.2 \%)$ & $20(74.1 \%)$ & 0.795 \\
$\quad$ never & $14(31.8 \%)$ & $7(25.9 \%)$ & 0.500 \\
\hline quit & $71.5(50-107)$ & $75(55-114)$ & 0.419 \\
\hline Median weight & $165(153-172)$ & $165(150-175)$ & 0.629 \\
\hline Median height & $27.18(19.72-39.9)$ & $27.55(20.44-41.02)$ & \\
\hline
\end{tabular}

BCS: Breast-conserving surgery, MRM: Modified radical mastectomy, BMI: Body mass index 
Elmas $\mathrm{O}$ et al.

Table 3: Comparison of the groups' average SF-36 scores

\begin{tabular}{|c|c|c|c|}
\hline Subscale & BCS group & MRM group & $\mathbf{P}$ \\
\hline Physical functioning & $67,16 \pm 17,23$ & $62,59 \pm 18,83$ & 0,299 \\
\hline Physical role functioning & $55,56 \pm 35,58$ & $47,73 \pm 39,92$ & 0,363 \\
\hline Emotional role functioning & $46,91 \pm 28,13$ & $43,18 \pm 30,99$ & 0,527 \\
\hline Vitality & $63,33 \pm 19,27$ & $54,89 \pm 19,90$ & 0,043 \\
\hline Mental health & $71,70 \pm 12,60$ & $63,18 \pm 18,13$ & 0,023 \\
\hline Social role functioning & $67,59 \pm 19,38$ & $67,11 \pm 28,12$ & 0,881 \\
\hline Bodily pain & $66,67 \pm 21,87$ & $65,91 \pm 26,01$ & 0,780 \\
\hline General health perceptions & $69,07 \pm 23,45$ & $62,84 \pm 20,07$ & 0,168 \\
\hline
\end{tabular}

BCS: Breast-conserving surgery, MRM: Modified radical mastectomy

as it is the case with all oncologic approaches. Body mass index, age, adjuvant RT and CT are all factors, that have been widely researched as affecting quality of life (6-8). Our research, however, found no statistically noteworthy difference of these factors and simply has, as its focal point, the comparison of what effects have the two different surgery types on quality of life.

In one of the earliest studies comparing the quality of life between BCS and MRM published by Ganz et al., found no significant differences between those two groups, when it comes to psychological reconciliation and quality of life (9). The authors have largely attributed this surprising outcome to RT performed after BCS. Since then, as research on the matter progressed, several studies have been published, stating that with presumably evolving surgical and RT techniques playing an important role, BCS patients' quality of life is much higher, than the ones who underwent MRM. Engel et al.'s work underlined BCS' superiority to MRM, concerning quality of life in all age groups and concluded that BCS should be ordered to any patient, regardless of age (10). A different study, conducted in Germany, found that the more time passed after the operation, the more apparent became the superior quality of life following BCS, as opposed to MRM (11). Notwithstanding the aforementioned research, a Japanese study reports the possibility of BCS patients, especially in the first few months post-surgery, suffering from higher levels of mental disturbances, linked to fear of relapse (12). Our research shows that quality of life scores in BCS patients are generally higher than MRM patients' scores, as similar with the literature, although the only metrics reflecting significant difference, as previously mentioned, are vitality and mental health.

A publication from Turkey, Kement et al., also compared the quality of life in BCS with MRM patients as well, stating that the values for all SF-36 subscales were higher in BCS patients, as opposed to MRM ones. However, their research showed all value differences to be statistically significant, except for the vitality and social role functioning aspects (13). Although utilizing a different survey in their research, Zanapalioglu et al.'s work underlines the argument, that BCS patients' quality of life is superior than MRM patients', by comparing general well-being, physical symptoms, role performance, emotional, cognitive and social role functioning, symptom control and body image in the aftermath of the two different surgery types (14).

Even though surveys specific to breast cancer patients like BR-23 survey are available (15), we used SF-36, which measures general quality of life in cancer patients. The most crucial argument to support this decision was the fact that its validity, as a measuring device, has been proven in Turkey.

As BCS is applied more often, number of MRM patients was lower than BCS patients and this was the limitation of our study.

To summarize, young patients who have undergone BCS scored higher on the quality of life measures set by the SF36 than MRM patients, especially highlighting a significant difference in the vitality and mental health aspects.

Taking into account the similarities of our work to research that has already been published, not only in Turkey but all around the world, the general assumption would be that patients' quality of life treated with BCS are much better than patients treated with MRM.

\section{Acknowledgment}

Not applicable.

\section{Author Contrubitons}

Authors indicated that all contributions are equal.

\section{Conflicts of Interest}

The authors declare that they have no conflict of interest. 


\section{Funding}

This research did not receive any specific grant from funding agencies in the public, commercial, or not-for-profit sectors.

\section{Ethical Approval}

This study was approved by local ethics committee of Zonguldak Bulent Ecevit University Clinical Research Ethics Committee (2018-162-20/06)

\section{Peer Review Process}

Extremely peer reviewed.

\section{REFERENCES}

1. Statistics at www.cancer.org. Accessed Jan 25, 2019.

2. Galway K, Black A, Cantwell M, Cardwell CR, Mills M, Donnelly M. Psychosocial interventions to improve quality of life and emotional well-being for recently diagnosed cancer patients. Cochrane Database Syst Rev 2012;11:CD007064.

3. Pinar R. Reliability and construct validity of the SF-36 in Turkish cancer patients. Qual Life Res 2005;14:259-264.

4. Bulak $\mathrm{H}$. Surgical management of breast carcinoma. Turkiye Klinikleri J Med Sci 1999;19:352-357.

5. Elmas Ö, Karadeniz Çakmak G, Bakkal BH. A comparison between breast-conserving surgery and modified radical mastectomy concerning the female sexual function in breast cancer patients under 50 years of age. Turk $\mathrm{J}$ Oncol 2020;35:26-30.

6. Cardoso MJ, Cardoso J, Santos AC, Vrieling C, Christie D, Liljegren G, Azevedo I, Johansen J, Rosa J, Amaral N, Saaristo $\mathrm{R}$, Sacchini V, Barros $\mathrm{H}$, Oliveira MC. Factors determining esthetic outcome after breast cancer conservative treatment. Breast J 2007;13:140-146.
7. Wang $H T$, Barone $C M$, Steigelman $M B$, Kahlenberg $M$, Rousseau D, Berger J, Daum A, Ortegon DP. Aesthetic outcomes in breast conservation therapy. Aesthet Surg J 2008;28:165-170.

8. Ozmen T, Polat AV, Kamali Polat A, Bonaventura M, Johnson $\mathrm{R}$, Soran $\mathrm{A}$. Factors affecting cosmesis after breast conserving surgery without oncoplastic techniques in an experienced comprehensive breast center. Surgeon 2015;13:139-144.

9. Ganz PA, Schag AC, Lee JJ, Polinsky ML, Tan SJ. Breast conservation versus mastectomy. Is there a difference in psychological adjustment or quality of life in the year after surgery? Cancer 1992;69:1729-1738.

10. Engel J, Kerr J, Schlesinger-Raab A, Sauer H, Hölzel D. Quality of life following breast-conserving therapy or mastectomy: Results of a 5-year prospective study. Breast J 2004;10:223231.

11. Arndt V, Stegmaier C, Ziegler H, Brenner H. Quality of life over 5 years in women with breast cancer after breast-conserving therapy versus mastectomy: A population-based study. J Cancer Res Clin Oncol 2008;134:1311-1318.

12. Shimozuma K, Sonoo H, Ichihara K, Miyake K, Kurebayashi J, Ota K, Kiyono T. The impacts of breast conserving treatment and mastectomy on the quality of life in early-stage breast cancer patients. Breast Cancer 1995;2:35-43.

13. Kement M, Gezen C, Aşik A, Karaöz A, Öven Ustaalioğlu B, Bilici A, Mustafa Ö. Meme kanserli Türk kadınlarında meme koruyucu cerrahi ve modifiye radikal mastektomi; yaşam kalitesine yönelik ileriye dönük bir analiz. Turkiye Klinikleri J Med Sci 2011;31:1377-1384.

14. Zanapalioğlu Y, Atahan K, Gür S, Çökmez A, Tarcan E. Effect of breast conserving surgery in quality of life in breast cancer patients. J Breast Health 2009;5:152-156.

15. O'Connell RL, DiMicco R, Khabra K, O'Flynn EA, deSouza N, Roche N, Barry PA, Kirby AM, Rusby JE. Initial experience of the BREAST-Q breast-conserving therapy module. Breast Cancer Res Treat 2016;160:79-89. 